\title{
Correlation between Individual Characteristics and Work Position with Work Fatigue on Workers
}

\author{
Hubungan Karakteristik Individu dan Posisi Kerja dengan Kelelahan Kerja pada \\ Pekerja
}

\author{
Irsyad Yudisianto ${ }^{1}$, Abdul Rohim Tualeka ${ }^{2}$, Noeroel Widajati ${ }^{3}$ \\ ${ }^{1}$ Master of Occuptional Health and Safety, Faculty of Public Health, Universitas Airlangga \\ ${ }^{2,3}$ Department of Occupational Safety and Health, Faculty of Public Heatlh, Universitas Airlangga \\ Campus C Mulyorejo, Surabaya 60115 East Java, Indonesia
}

\begin{abstract}
Introduction: Work fatigue is a condition of decreased efficiency and resilience of workers, which can interfere the companys' productivity. Job fatigue can be caused by the performance, duration, and effort (work position) of the workers. Based on the observations, workers at the expedition sub units of PT X needed to lift 200 to $400 \mathrm{~kg}$ heavy loads. The activity of lifting very heavy weights can cause fatigue. One form of physical fatigue indicators is an increase in lactic acid in the blood. The purpose of this study was to analyze the correlation between workers' characteristics and work position with work fatigue among workers in the expedition sub units of PT X. Methods: This research was a quantitative study with a cross sectional design. The population of this study was 36 people. This research used total sampling. The independent variable were individual characteristics and work position as measured using REBA tools, and the dependent variable was work fatigue as measured using lactic acid levels in blood. Data was analyzed using statistical tools to obtain the value of correlation coefficient between variables. Result: The results showed that there was a weak positive correlation between workers' characteristics and physical fatigue. The results showed that the coefficient value between work position and physical fatigue was 0.354 . The coefficient figure indicated a weak positive correlation between work position and work fatigue. Conclusion: There was a correlation between work position and work fatigue in workers.
\end{abstract}

Keywords: ergonomics, lactic acid, REBA, work fatigue, work position

\section{ABSTRAK}

Pendahuluan: Kelelahan kerja merupakan kondisi turunnya efisiensi dan ketahanan pekerja yang dapat mengganggu produktifitas perusahaan. Kelelahan kerja disebabkan karena tingkat kinerja, durasi, dan effort (posisi kerja) dari pekerja. Berdasarkan pengamatan pekerjaan di sub unit ekpedisi PT X mengharuskan pekerja untuk selalu mengangkat beban berat 200 hingga 400kg. Kegiatan mengangkat beban yang sangat berat ini dapat menimbulkan kelelahan. Salah satu bentuk kelelahan kerja secara fisik adalah adanya peningkatan asam laktat di dalam darah. Tujuan dari penelitian ini adalah menganalisis hubungan antara karakteristik pekerja, dan posisi kerja dengan kelelahan kerja pada pekerja di bagian sub unit ekspedisi perusahaan X. Metode: Penelitian ini merupakan penelitian kuantitatif dengan rancang bangun cross sectional. Jumlah populasi adalah 36 orang. Penelitian ini menggunakan seluruh populasi yang berjumlah 36 orang. Variabel independen yang diteliti adalah karakteristik Individu, posisi kerja yang diukur dengan tools REBA, dan variabel dependen adalah kelelahan kerja yang diukur dengan kadar asam laktat dalam darah. Data penelitian diuji dengan uji asosiasi melalui aplikasi statistik untuk mendapatkan nilai koefisien hubungan antar variabel. Hasil: Hasil penelitian menunjukkan adanya hubungan positif yang lemah antara karakteristik pekerja dengan kelelahan fisik. Hasil menunjukkan adanya hubungan antara posisi kerja dengan kelelahan fisik besar nilai koefisien 0,354. Angka koefisien tersebut menunjukkan adanya hubungan positif yang lemah antara posisi kerja dengan kelelahan kerja. Simpulan: Terdapat hubungan antara posisi kerja dengan kelelahan kerja pada pekerja.

Kata kunci: asam laktat, ergonomi, kelelahan kerja, posisi kerja, REBA

Corresponding Author:

Irsyad Yudisianto

Email: irsyadyudis@gmail.com

Telephone: +6281331000874

\section{INTRODUCTION}

The workload greatly affects workers. The workload must be balanced on the physical, cognitive abilities and limitations of the ability

(C2021 IJOSH All right reserved. Open access under CC BY NC-SA license doi:10.20473/ijosh.v10i3.2021.350-360 Received June 14, 2020, received in revised form October 02, 2020, Accepted August 13, 2021, Published: December 2021 
of workers (Eko, 2014). Workers who have an excessive workload will experience physical fatigue (headaches, indigestion, etc.) and psychological fatigue (emotional exhaustion, stress, etc.). On the other hand, if the workload is light, workers will be bored. Workers' boredom will eventually have impact on the decrease in performance motivation (Annisa and Farihah, 2018).

The decrease in performance efficiency and effectiveness is closely related tofatigue. Fatigue indications vary among workers. Fatigue reduces work capacity, but at the same time fatigue can also become a defense to protect the body from serious damage, so the body can be immediately recovered (Umyati, 2010). Based on Ningrum (2012), fatigue occurs due to buildup of lactic acid in the tissue. It makes the body unable to neutralise the lactic acid mass or the lactic acid growth. This can happen because of the workers get a heavy workload.

The amount of lactic acid or lactate levels in the blood is proportional to the levels of lactic acid in a person's muscles (Hidayah, 2018). Blood lactic acid levels range from $0.9-1.3 \mathrm{mmol} / \mathrm{l}$ at rest. Muscle lactic acid levels range from $0.9-3.1 \mathrm{mmol} / \mathrm{kg}$ at rest (Gorostiaga et al., 2014). Muscle and blood lactic acid concentrations attain individual maximum levels up to $15-25 \mathrm{mmol} / \mathrm{l}$ (Gorostiaga et al., 2010). The normal blood lactic acid value in humans is 1.0$2.0 \mathrm{mmol} / \mathrm{l}$ (Jia, Wang and $\mathrm{Yu}, 2017$ ). Sari shows that lactic acid levels are normally at $0-4 \mathrm{mmol} / 1$ (Sari, Endardjo and Santoso, 2013). The increase in lactic acid in the blood which exceeds $4 \mathrm{mmol} / 1$ and does not reduce after resuscitation indicates the probability of organ damage (Leksana, 2010).

Apart from elevated levels of lactic acid, other factors that cause fatigue are work positions, static jobs and non ergonomic work stations. This is in accordance with research of Gandung (2011), which explained that when the body is in a static position, there will be a blockage of blood flow which results in a lack of oxygen and glucose from the blood. Moreover, Budhiman (2015) analyzed the level of ergonomic risk using the REBA (Rapid Entire Body Assessment), OWAS (Ovako Working Posture Analysis System) and QEC (Quick Exposure Checklist) methods. It was found that most workers in a standing work position had a high level of ergonomic risk and fatigue, so the condition had to be repaired immediately.

PT $X$ is located in Surabaya City. PT $X$ is a sack manufacturing company. PT $\mathrm{X}$ has 1.222 workers with 36 workers in the expedition sub unit. Working hours at PT X starts from 07.00 to 14.00 on weekdays, while on Saturdays it operates from 07.00 am to $13.00 \mathrm{pm}$. On Sundays PT X is closed.

Based on the preliminary observations and interviews to the workers in the expedition sub-unit of PT. X, it is known that non neutral job position (awkward position), lifting, pushing, pulling without ergonomics, and standing work rhythm without rest sitting for 4 hours could accelerate the occurrence of work fatigue. Workers also felt tired when they did a few hours of work because there were rules about not being allowed to sit while working. Job demands must be balanced with individual work capacity, so excessive work demands do not happen. Excessive job demands can cause fatigue. Workers who are exhausted have the potential to experience decreased productivity and work accidents. The purpose of this research is, therefore, to analyze the correlation between work position and physical fatigue among workers in the expedition sub unit at PT X.

\section{METHODS}

This research is an observational study with a quantitative approach. Data were obtained through observations of workers in the expedition sub unit including in the circular loom and jumbo bag sub units at PT X. Population in this research was 36 workers. This research used a total sampling of 36 workers. The design of this study used a cross sectional design because the independent and dependent variables were only assessed and described at one specific time period (Nursalam, 2013). This study has obtained an ethical clearance certificate No. 312/ HRECC.FODM/VII/2020. The research was conducted in April-May 2020.

The independent variable in this study was the individual characteristics, work position measured using the REBA posture calculation method. The work position of the workers in this study is a posture that is naturally formed by the body of the worker which interacts with the work habits and facilities used in a job. The risk types of work position were divided into 5 categories as show in Table 1.

Table 1. Risk Category Based on REBA

\begin{tabular}{lc}
\hline \multicolumn{1}{c}{ Category } & Score \\
\hline Acceptable risk & 1 \\
Low risk & $2-3$ \\
Moderate risk & $4-7$ \\
High risk & $8-10$ \\
Very high risk & $\geq 11$ \\
\hline
\end{tabular}


The dependent variable in this study was physical fatigue, measured using the amount of lactic acid in the blood as a reference. Physical fatigue in this research was based on the results of measuring levels of lactic acid in workers. Lactic acid levels in this research were measured after workers had completed working hours at the company. Measurements of lactic acid levels in workers' blood were carried out twice, before and after work. Blood sampling and measurement of lactic acid levels in the blood were carried out by laboratory staff of the Faculty of Public Health, Airlangga University. The data on physical fatigue variables were divided into 3 categories, not tired $(0-2 \mathrm{mmol} / \mathrm{l})$, tired $(2-4 \mathrm{mmol} / \mathrm{l})$, and very tired ( $>4$ $\mathrm{mmol} / \mathrm{l})$.

The risk levels of work positions were categorized into acceptable, low, medium, high, and very high, as shown as a frequency table. The data from the measurements of physical fatigue with lactic acid were categorized as fatigue levels including not tired, tired, and very tired, shown as a frequency table. The risk levels of work attitudes would be analyzed using the correlation test by looking at the correlation coefficient. The correlation coefficient was used to analyze the relationship between work position and work fatigue. The results of the coefficient from the association test were analyzed with the association number guide from Sugiyono (2008) in the following order: Coefficient association $0.00-0.199$ means very weak correlation, $0.20-0.399$ means weak correlation, $0.40-0.599$ means moderate correlation, 0.60 0.799 means strong correlation, and $0.80-1,000$ means very strong correlation.

The collected data were further re-examined through the editing process. Data that had passed the editing process were then processed and analyzed. This research also used the Spearman correlation test for the ordinal scales and coefficient contingency test for the nominal scale. The results of data analysis were quantitative and were presented as narrative and descriptive tables.

\section{RESULTS}

\section{Workers' Characteristics in the Expedition Sub Unit at PT X}

The characteristics of the workers in the circular loom and jumbo bag sub units were divided into age, sex, and Body Mass Index (BMI). Tables 2-4 show the workers' characteristics in the circular loom and jumbo bag sub units at PT X in 2020.

Based on Table 2, it is found that workers at PT $\mathrm{X}$, especially in the circular loom and jumbo bag sub units, were mostly in the age range of 36 - 46 years old with a total of 16 people or $44.4 \%$. Meanwhile, the sex characteristics of the workers in circular loom and jumbo bag sub units at PT X are illustrated in Table 3.

Based on Table 3, it is found that workers who worked at PT X, especially in the circular loom and jumbo bag sub units were males, accounting for $91.7 \%$. The next characteristic of workers is BMI. Table 4 shows the BMI characteristics of workers in the circular loom and jumbo bag sub units at PT. $\mathrm{X}$ in 2020.

Based on Table 4, it is found that the workers BMI in circular loom and jumbo bag sub units were mostly in the normal range, $18.01-25.00$,

Table 2. Characteristics of Age of Workers in the Circular Loom and Jumbo Bag Sub Units of PT. X Year 2020

\begin{tabular}{lcc}
\hline \multirow{2}{*}{\multicolumn{1}{c}{ Age }} & \multicolumn{2}{c}{ Frequency } \\
\cline { 2 - 3 } & n & \% \\
\hline$<25$ years old & 5 & 13.9 \\
26-35 years old & 2 & 5.6 \\
$36-46$ years old & 16 & 44.4 \\
$>46$ years old & 13 & 36.1 \\
\hline \multicolumn{1}{c}{ Total } & 36 & 100 \\
\hline
\end{tabular}

Table 3. Gender Characteristics of Workers in the Circular Loom and Jumbo Bag Sub Units at PT. X Year 2020

\begin{tabular}{lcc}
\hline \multirow{2}{*}{ Sex } & \multicolumn{2}{c}{ Frequency } \\
\cline { 2 - 3 } & n & \% \\
\hline Male & 33 & 91.7 \\
Female & 3 & 8.3 \\
\hline \multicolumn{1}{c}{ Total } & 36 & 100 \\
\hline
\end{tabular}

Table 4. BMI Characteristics of Workers in the Circular Loom and Jumbo Bag Sub Units at PT. X Year 2020

\begin{tabular}{lcc}
\hline \multirow{2}{*}{ IMT } & \multicolumn{2}{c}{ Frequency } \\
\cline { 2 - 3 } & $\mathbf{n}$ & $\mathbf{\%}$ \\
\hline Skinny $<17-18.00$ & 2 & 5.6 \\
Normal $18.01-25.00$ & 24 & 66.7 \\
Overweight $25.01-27.00$ & 4 & 11 \\
Obesity $>27.01$ & 6 & 16.7 \\
\hline \multicolumn{1}{c}{ Total } & 36 & 100 \\
\hline
\end{tabular}


Table 5. Work Position of Workers in the Circular Loom and Jumbo Bag Sub Units at PT. X Year 2020

\begin{tabular}{|c|c|c|c|c|c|c|}
\hline \multirow{3}{*}{ Sub Unit } & \multicolumn{6}{|c|}{ Work Position } \\
\hline & \multicolumn{2}{|c|}{$\begin{array}{c}\text { Mo d e r a t e } \\
\text { Risk }\end{array}$} & \multicolumn{2}{|c|}{ High Risk } & \multicolumn{2}{|c|}{$\begin{array}{c}\text { Very High } \\
\text { Risk }\end{array}$} \\
\hline & $\mathrm{n}$ & $\%$ & $n$ & $\%$ & $n$ & $\%$ \\
\hline $\begin{array}{l}\text { Circular } \\
\text { Loom }\end{array}$ & 3 & 16.7 & 7 & 38.9 & 8 & 44.4 \\
\hline Jumbo Bag & 3 & 16.7 & 4 & 22.2 & 11 & 61.1 \\
\hline Total & 6 & 16.7 & 11 & 30.6 & 19 & 52.8 \\
\hline
\end{tabular}

Table 6. Physical Fatigue of Workers in the Circular Loom and Jumbo Bag Sub Units at PT. X Year 2020

\begin{tabular}{ccccc}
\hline & \multicolumn{4}{c}{ Physical Fatigue } \\
\cline { 2 - 5 } Sub Unit & Tired (2-4 mmol/l) & $\begin{array}{c}\text { Very } \\
\text { Tired } \\
\text { mmol/l) }\end{array}$ & $\mathbf{( > 4}$ \\
\cline { 2 - 5 } & $\mathbf{n}$ & $\mathbf{\%}$ & $\mathbf{n}$ & $\mathbf{\%}$ \\
\hline $\begin{array}{c}\text { Circular } \\
\text { Loom }\end{array}$ & 17 & 94.4 & 1 & 5.6 \\
$\begin{array}{c}\text { Jumbo } \\
\text { Bag }\end{array}$ & 11 & 61.1 & 7 & 38.9 \\
\hline Total & 28 & 77.8 & 8 & 22.2 \\
\hline
\end{tabular}

accounting for 24 people or $66.7 \%$ of total workers.

\section{Work Position of Workers in the Expedition Sub Unit at PT X}

The work position of the workers in this research is a posture that is naturally formed by the body of the worker who interacts with work habits and facilities used in a job. Work positions of workers in the circular loom and jumbo bag sub units at PT X in 2020 are shown in Table 5.

Based on Table 5, it is found that the work position of workers in the circular loom and jumbo bag sub units at PT X in 2020 was at a very high risk with a REBA score of 11-15, accounting for $52.8 \%$ or 19 people. Most of the workers in the circular loom sub unit (44.4\%) experienced work positions with a very high risk. Meanwhile, most of the workers in the jumbo bag sub-units experienced work positions with a very high risk, accounting for approximately $61.1 \%$.

\section{Physical Fatigue of Workers in the Expedition Sub Unit at PT X}

The observation of physical fatigue in this research used the results of the measurements of
Table 7. Cross Tabulation between Workers' Age and Physical Fatigue in the Circular Loom and Jumbo Bag Sub Units at PT X Year 2020

\begin{tabular}{lcccc}
\hline & \multicolumn{5}{c}{ Physical Fatigue } \\
\cline { 2 - 5 } Age & Tired (2-4 mmol/l) & Very & $\begin{array}{c}\text { Tired } \\
\text { mmol/l) }\end{array}$ & $(>\mathbf{4}$ \\
\cline { 2 - 5 } & $\mathbf{n}$ & $\mathbf{\%}$ & $\mathbf{n}$ & $\mathbf{\%}$ \\
\hline $\begin{array}{l}>25 \text { years } \\
\text { old } \\
26-35\end{array}$ & 5 & 100 & 0 & 0 \\
$\begin{array}{l}\text { years old } \\
36-46 \\
\text { years old } \\
>46 \text { years } \\
\text { old }\end{array}$ & 11 & 68.8 & 5 & 31.2 \\
\hline \multicolumn{1}{c}{ Total } & 10 & 76.9 & 3 & 23.1 \\
\hline
\end{tabular}

lactic acid levels in workers. Lactic acid levels in the study were measured after workers had completed work hours at the company. Table 6 shows the physical fatigue of the workers in the circular loom and jumbo bag sub units at PT X in 2020.

Based on Table 6, it is found that the workers in the circular loom and jumbo bag sub units at PT $\mathrm{X}$ in 2020 mostly (77.8\%) experienced physical fatigue which was included in the tired category. Total lactic acid levels in the blood were in the range of $2-4 \mathrm{mmol} /$ liter. Most of the workers in the circular loom sub unit (94.4\%) experienced physical fatigue, which was included in the tired category. Meanwhile, workers in the jumbo bag sub unit at PT. X in 2020 mostly (61.1\%) experienced physical fatigue in the tired category.

\section{Correlation between Workers' Characteristics and Physical Fatigue}

Based on Table 7, we get information about the distribution of workers' age and physical fatigue level in the circular loom and jumbo bag sub units at PT X in 2020. Most of the workers aged over 36 years old experienced physical fatigue which was included in tired category. Lactic acid mass value in the blood was 2-4 mmol / liter. More specifically, the age range of 36-46 years old (68.8\%) experienced physical fatigue which was included in the tired category. Workers with an age over 46 years old (76.9\%) experienced physical fatigue which was included in the tired category.

Based on the results of the statistical test using association test, the value of the association coefficient was 0.267 . This figure means that there 
Table 8. Cross Tabulation between sex with Physical Fatigue in the Circular Loom and Jumbo Bag Sub Units at PT. X in 2020

\begin{tabular}{ccccc}
\hline & \multicolumn{3}{c}{ Physical Fatigue } \\
\cline { 2 - 5 } Sex & \multicolumn{2}{c}{$\begin{array}{c}\text { Tired(2-4 } \\
\text { mmol/l) }\end{array}$} & \multicolumn{2}{c}{$\begin{array}{c}\text { Very Tired ( }>\text { 4 } \\
\text { mmol/l) }\end{array}$} \\
\cline { 2 - 5 } & $\mathbf{n}$ & $\mathbf{\%}$ & $\mathbf{n}$ & $\mathbf{\%}$ \\
\hline Male & 25 & 75.8 & 8 & 24.2 \\
Female & 3 & 100 & 0 & 0 \\
\hline Total & 28 & 73.3 & 8 & 26.7 \\
\hline
\end{tabular}

Table 9. Cross Tabulation between BMI with Physical Fatigue in the Circular Loom and Jumbo Bag Sub Unit of PT X in 2020

\begin{tabular}{|c|c|c|c|c|}
\hline \multirow{3}{*}{ BMI } & \multicolumn{4}{|c|}{ Physical Fatigue } \\
\hline & \multicolumn{2}{|c|}{ Tired (2-4 mmol/l) } & \multicolumn{2}{|c|}{$\begin{array}{l}\text { Very } \begin{array}{r}\text { Tired } \\
\mathrm{mmol} / \mathrm{l})\end{array}\end{array}$} \\
\hline & $\mathbf{n}$ & $\%$ & $\mathrm{n}$ & $\%$ \\
\hline $\begin{array}{l}\text { Skinny }(<17 \\
-18,00)\end{array}$ & 2 & 100 & 0 & 0 \\
\hline $\begin{array}{l}\text { Normal } \\
(18,00- \\
25,00)\end{array}$ & 20 & 83.3 & 4 & 16.7 \\
\hline $\begin{array}{l}\text { Overweight } \\
(25,01- \\
27,00)\end{array}$ & 2 & 50 & 2 & 50 \\
\hline $\begin{array}{l}\text { Obesity } \\
(>27,01)\end{array}$ & 4 & 66.7 & 2 & 33.3 \\
\hline Total & 28 & 77.8 & 8 & 22.2 \\
\hline
\end{tabular}

was a positive relationship between workers' age with physical fatigue in the circular loom and jumbo bag sub units of PT X. The correlation coefficient value was 0.267 indicating that the relationship between the characteristics of workers' age and physical fatigue in the circular loom and jumbo bag sub units at PT X was weak.

Table 8 shows the distribution of workers' sex and physical fatigue in the circular loom and jumbo bag sub units at PT X in 2020. Most of the male workers experienced physical fatigue which was included in the category tired. Lactic acid mass value $\mathrm{t}$ in the blood was $2-4 \mathrm{mmol} /$ liter. More specifically, $75.8 \%$ of male workers experienced physical fatigue which was included in the tired category.

Based on the results of the statistical test with the association test, the value of the association coefficient was 0.159 . This figure means that there was a positive relationship between sex physical fatigue in the circular loom and jumbo bag sub units
Table 10. Cross Tabulation between Work Position and Physical Fatigue in the Circular Loom and Jumbo Bag Sub Units at PT. X Year 2020

\begin{tabular}{|c|c|c|c|c|}
\hline \multirow{3}{*}{$\begin{array}{l}\mathbf{W} \underset{\text { Position }}{\mathbf{r}} \mathbf{k} \\
\text { Pos }\end{array}$} & \multicolumn{4}{|c|}{ Physical Fatigue } \\
\hline & \multicolumn{2}{|c|}{ Tired (2-4 mmol/l) } & \multicolumn{2}{|c|}{$\begin{array}{rr}\text { Very } \begin{array}{r}\text { Tired } \\
\mathrm{mmol} / \mathrm{l})\end{array} \\
\end{array}$} \\
\hline & $\mathbf{n}$ & $\%$ & $\mathbf{n}$ & $\%$ \\
\hline $\begin{array}{l}\text { Moderate } \\
\text { Risk }\end{array}$ & 6 & 100 & 0 & 0,0 \\
\hline High Risk & 10 & 90.9 & 1 & 9.1 \\
\hline $\begin{array}{l}\text { Very High } \\
\text { Risk }\end{array}$ & 12 & 63.2 & 7 & 36.8 \\
\hline Total & 28 & 77.8 & 8 & 22.2 \\
\hline
\end{tabular}

at PT X. The correlation coefficient value of 0.159 showed that the correlation between sex and physical fatigue in circular loom and jumbo bag sub units at PT X was very weak.

Based on Table 9, it is found that the distribution between workers' BMI and physical fatigue in the circular loom and jumbo bag sub units at PT X in 2020 was dominated by workers with a BMI of $18.01-25.00$ of $83.3 \%$, or 20 workers experienced physical fatigue which was included in the tired category. Lactic acid mass value in the blood was 2-4 mmol / liter.

Based on the statistical test results using association test, the value of the association coefficient between BMI and physical fatigue in the circular loom and jumbo bag sub units at PT $\mathrm{X}$ in 2020 was 0.286 . This figure means that there was a positive association between BMI and physical fatigue in the circular loom and jumbo bag sub units at PT X. The correlation coefficient value (0.286) shows that the correlation between BMI physical fatigue in circular loom and jumbo bag sub units at PT X was weak.

\section{Correlation between Work Position and Physical Fatigue}

Table 10 shows the distribution between work position and physical fatigue experienced by workers in the circular loom and jumbo bag sub units at PT. X in 2020. Most of the workers (90.9\%) with high risk work positions experienced physical fatigue which was included in the tired category. Meanwhile, most of the workers with very high risk work positions $(63.2 \%)$ experienced a level of physical fatigue which was included in the tired category. 
The statistical tests results using the association test showed that the value of the association coefficient between work position and physical fatigue was 0.354 . This figure means that there was a positive correlation between work position and physical fatigue in the circular loom and jumbo bag sub units at PT X. In addition, the association coefficient figure of 0.354 also means that the relationship between work position and physical fatigue in the circular loom and jumbo bag sub units at PT X was weak.

\section{DISCUSSION}

\section{Workers' Characteristics in the Expedition Sub Unit at PT X}

The characteristics of the workforce in this research consisted of age, sex and BMI. Age is one sign of the process of human life. The human process of aging will be in line with reduced abilities and changes in the performance of the body's organ systems (Suma'mur, 2009). From the research results, it was found that most of the workers aged $36-46$ years old $(43.3 \%)$ were in the productive ages, ready to accept and carry out work. Hasibuan (2016) said that workers with a productive and young age generally strong, dynamic, and creative compared to older workers.

According to Suma'mur (2009) and Tarwaka (2014), there are some differences between men and women in doing a job. Women tend to be more prone to fatigue than men. The results showed that most of the workers were males. Undeniably, job descriptions in the circular loom and jumbo bag sub units require muscle performance and muscle strength, so that male workers tend to be less prone to fatigue which may hamper a job.

Another workers' characteristic is BMI which is an indicator of a person's nutritional status. Nutritional status affects the productivity of a worker. Lack of nutrients in a person's body will affect the person's health condition and in the end will affect their productivity at work (Widiastuti and Dieny, 2015).

\section{Work Position in the Expedition Sub Unit at PT $\mathbf{X}$}

Work position is a posture that is naturally formed by the body due to the interaction of the body with all facilities during work. Work position is one of the important factors for a worker to achieve job effectiveness (Sulaiman and Sari, 2016). Most of the work positions in the circular loom and jumbo bag sub units at PT. X were included in the very high risk category $(52.8 \%)$. The work position in the very high category needs to be changed immediately. One of the most common working positions is arm and leg movement.". That movement is needed to move raw materials. Ergonomic work positions can help reduce health problems related to work posture such as injuries to body movements, help reduce workloads, and help reduce fatigue experienced by workers (Jalajuwita and Paskarini, 2015). To give more details about the calculation of work positions, Figure 1 shows a sample calculation of workers' position at PT X in 2020.

Figure 1 shows there are several work positions that require more physical effort. The angle of the head position is $45^{\circ}$ but the neck position of the worker is tilted to the side, so the score is 3 . The torso bent $45^{\circ}$ and turning / tilted to the side contributes to the greater score for the REBA score. The feet position is also not ergonomic where the feet tare not supported or unstable. The angle formed from the knee position is $30^{\circ}$, and the feet position contributes to the REBA, so the score is 3 . The weigh load that is lifted by the worker is $60 \mathrm{~kg}$, which is lifted very quickly. The neck, torso and leg position score calculation results in 11 points for sample 1. The position of the neck, torso and legs indicates that the position of the worker is unstable, is awkward, and requires a lot of energy to do it.

Analysis of the position of the upper arm, forearm and wrist of the worker results in 8 points

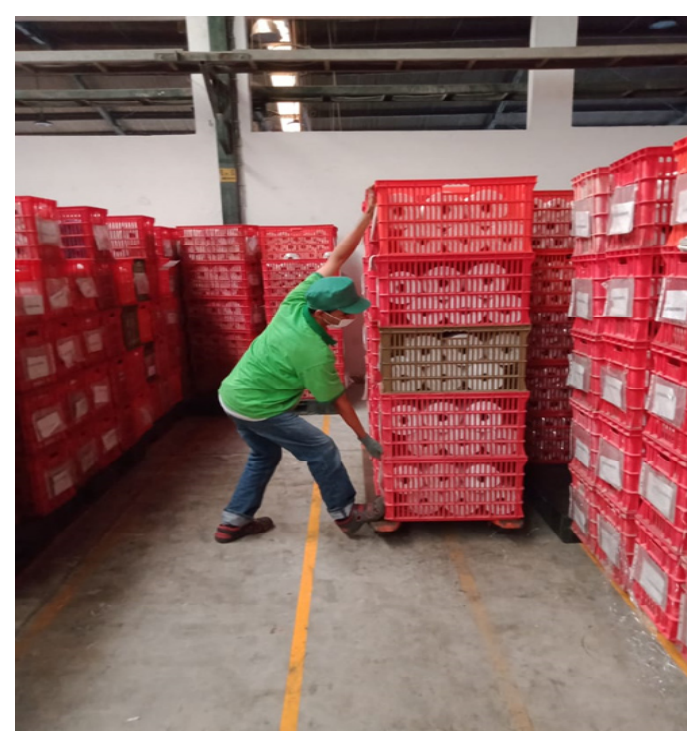

Figure 1. Sample Calculation of PT X's Workforce Position in 2020 
in a REBA score. In more detail, based on Figure 1, it is known that there are several positions that are not ergonomic. The angle of the forearm position is $60^{\circ}$, and the shoulders are raised; this indicates that the upper arm is unstable and awkward. The angle of the forearm position is $<60^{\circ}$, repeated for lifting heavy weights requiring a lot of muscle activity and exertion. The position of the wrist is $0^{\circ}$ forwardsideways, causing the muscles to be more active and require a lot of energy to do so.

Based on the a fore mentioned position analysis, the final REBA score is 13. The Aforementioned positions are categorized as very high risk work positions so that they need to be improved and changed now or as soon as possible.

The work position is influenced by the activities carried out during work. The work in the circular loom and jumbo bag sub units at PT. X is carried out in a standing work position. Based on the results, we found that most of the occupational risk category for workers in the circular loom and jumbo bag sub unit at PT. X were in the very high category. Result showed that the efforts to minimize work positions that require a lot of movement from the body have not been maximized, causing the emergence of unnatural work positions.

Based on Ministry of Manpower Regulation Number 5 Year 2018 concerning the Safety and Occupational Health, the work of workers in the circular loom and jumbo bag sub units at PT. X included repetitive manual work lifting, carried out

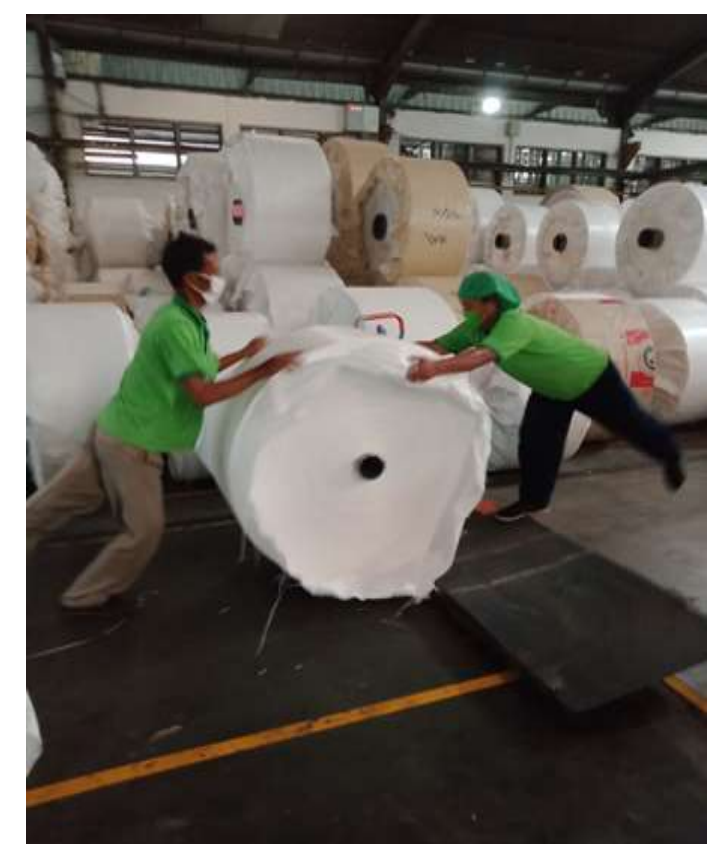

Figure 2. Sample Work in the Jumbo Bag Sub Unit in one day period. Figure 2 shows the sample of work of workers in the jumbo bag sub unit. This can be used to analyze more precisely the work position in the circular loom and jumbo bag sub units at PT. $\mathrm{X}$.

Based on Figure 2, it is known that the work position does not meet the requirements to reduce the load limit as workers lift objects that are difficult to hold in an unstable standing position, or the lifting position is not being supported by both legs properly. The lifting duration was $>2$ hours per day with lifting frequency $<12$ times per day. Moreover, based on the Ministry of Manpower Regulation Number 5 Year 2018 concerning the Safety and Occupational Health, the horizontal range zone of the workers should be $60-80 \mathrm{~cm}$, which is not applicable in the physical work of the workers in this study. Regarding the vertical zone of the work position in Figure 2, the zone between the lower and upper shoulders with a medium distance $(30-60 \mathrm{~cm})$ has a weight threshold value of $7 \mathrm{~kg}$, while workers in this research area brought the load of more than $15 \mathrm{~kg}$. Furthermore, the zone between the grip height and shoulder has an extended distance $(>60-80$ $\mathrm{cm}$ ), and any load cannot be tolerated. Based on this description, it can be concluded that the work position of the workers in the jumbo bag sub unit (Figure 2) was not accordance with the standards set in the Ministry of Manpower Regulation Number 5 Year 2018 regarding the Safety and Occupational Health.

Figure 3 below shows the work sample in the circular loom sub unit. This sample was used to analyze more precisely the work position of the workers in the circular loom sub unit at PT. X.

Based on Figure 3, it is known that the work position of the workers is still not in accordance with the recommendations from the Ministry of Manpower Regulation Number 5 Year 2018 concerning the Safety and Occupational Health. The legs are not well supported, the body is twisted and the arms are in an unusual lifting position. Lifting duration is more than 2 hours per day with lifting frequency less than 12 times per hour for a single batch, repeated in one work period. Figure 3 also shows that the the lifting task of the worker starts and ends more than $30 \mathrm{~cm}$ above the shoulder or more than $180 \mathrm{~cm}$ above the floor. Meanwhile, for the vertical zone, it is known that the zone between the bottom of the shoulder and the top of the shoulder exceeds the specified limit of $30 \mathrm{~cm}$, and is more than $8 \mathrm{~cm}$ below the height of the shoulder. The 
horizontal zone distance of the shoulders is 30$60 \mathrm{~cm}$, with a recommended weight limit of $7 \mathrm{~kg}$. Meanwhile, in Figure 3 the load being lifted is more than $20 \mathrm{~kg}$. This shows that the work position of the sample in the circular loom sub unit does not comply with the standard of the regulations.

Figure 4 shows a sample of administrative work in the circular loom and jumbo bag sub units for a more precise analysis of the work position of the workers in the circular loom and jumbo bag sub units at PT. X.

In Figure 4, there are of administrative work in the circular loom and jumbo bag sub units. Based on the Ministry of Manpower Regulation Number 5 Year 2018 concerning the Safety and Occupational Health, work positions for jobs that require precision, such as administration, have two choices, namely sitting and standing. However, in the sample of administrative work in Figure 4, it can be seen that for administrative workers, a standing work position is not in accordance with the aforementioned regulations.

A standing work position is generally found in assembly, automotive and other industrial companies that require alertness both physically and mentally. For work that requires height and precision, the

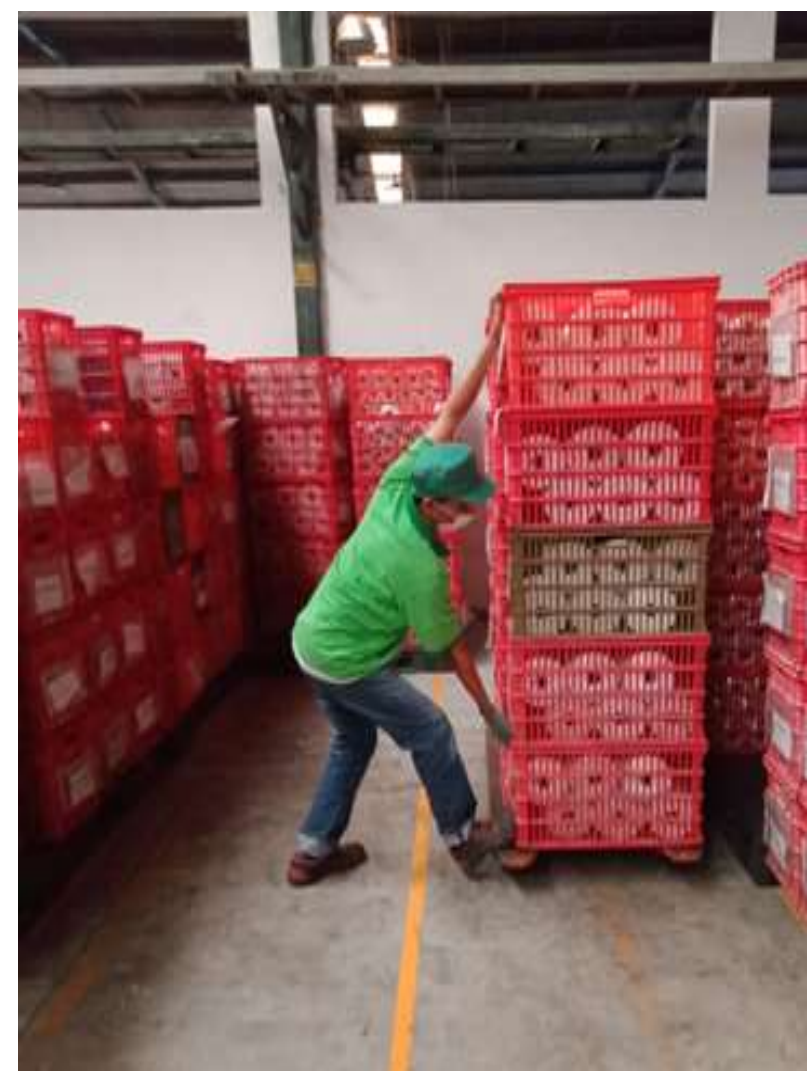

Figure 3. Work Sample in the Circular Loom Sub Unit height of the work base is $5-10 \mathrm{~cm}$ above the height of the standing elbow. Based on Figure 4, it is known that the base height has a lower height and is at the elbow height line. In addition, the visual display in Figure 4 shows the upper limit of the field view within the normal limits $(<5 \%)$ for the workforce (women). Meanwhile, for male workers, in Figure 4, it is known that the visual display exceeds the upper limit of the field view ( $>5 \%$ ) above the horizontal line of sight.

In addition, Figure 4 shows that work area requirements are not fulfilled properly. These requirements include the work dimension of the computer desk of male administrative staff. It is widely known that work table height is on a line to the elbow height. In the Ministry of Manpower Regulation Number 5 Year 2018 concerning Safety and Occupational Health, the guidelines for the height of a work desk with a standing work position are $10-20 \mathrm{~cm}$ higher than the elbow. Based on these regulations, for jobs that require accuracy, the best work posture is a sitting position so that it can reduce muscle fatigue. Thus, based on the above discussion, it can be concluded that the work position in Figure 4 is an inadequate work position for administrative work.

\section{Correlation between Individual Characteristics and Physical Fatigue}

The results of this research showed that there was a very weak and insignificant positive

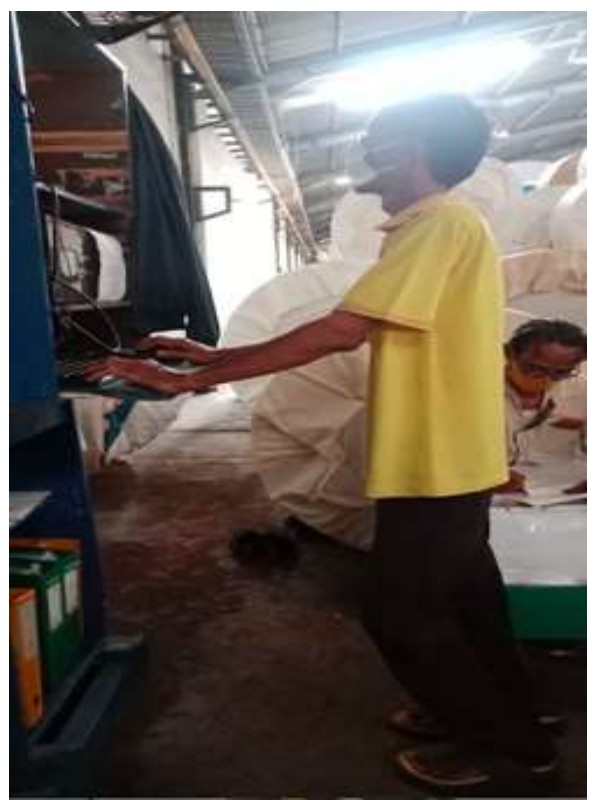

Figure 4. Sample of the Administrative Work in the Circular Loom and Jumbo Bag Sub Units 
correlation between individual characteristics and physical fatigue. The results of the study are not in accordance with the statement from Suma'mur (2009) stating that the factors that influenced physical fatigue were age and BMI. However, the lactic acid in the blood did not have a relationship with age and BMI according to the results of research from Setiadi (2015). Physical fatigue in this research used an indicator of increased levels of lactic acid in the blood of workers.

The weak correlation between individual characteristics (age and BMI) and physical fatigue is probably due to the similarity of job descriptions in the circular loom and jumbo bag sub units. Work activities in the circular loom and jumbo bag sub units require workers to move intensively. The movement of the limbs required for the job causes a continuous contraction of the workers' muscles. This work applies to all workers regardless of age or workers' posture. This causes the weak correlation between individual characteristics and physical fatigue.

Age causes a decrease in the muscle and joint function as with the increase in age, the mitochondria in muscles decreases. The decrease in mitochondria causes a decrease in the respiratory capacity of muscles to absorb oxygen from red blood cells, which causes fatigue to occur due to an increase in lactic acid levels (Kurnianto, 2015). BMI has a significant relationship with the maximum oxygen volume, so an individual with a normal BMI will have a better oxygen volume saturation (Andriani, 2016). Barnes in Setyawati shows that lactic acid is produced by the body when the body's muscles contract (Setyawati, 2010). The restoration of deep muscle function is affected by the supply of oxygen from red blood cells which is distributed throughout the body, including the muscles. Based on the results of the study, it was found that BMI had a positive relationship with lactic acid levels in the blood of workers. This is in accordance with the results of Andersen's research which showed that $83.3 \%$ of workers with normal BMI had lactic acid levels after work in the range of $2.0-4.0 \mathrm{mmol} /$ liter of blood. The lactic acid levels were still in the range that did not harm the body (Andersen, 2013).

The results of the study provide information that there was a weak positive correlation between sex and physical fatigue. The results of research from Hidayah (2018) showed that the males did not have a tendency to experience muscle fatigue as indicated by the level of lactic acid in the blood. This is inconsistent with the results of this study, which showed a weak positive correlation. The results of the study are in accordance with the statement from Tarwaka (2014) which stated that men had slightly higher aerobic energy than women. In addition, there were various factors outside the research that influenced the workers' fatigue level. The smoking habit of male workers may be related to the relationship between sex and physical fatigue.

\section{Correlation between Work Position and Physical Fatigue}

The correlation between work position and physical fatigue in this study showed a weak positive correlation. In addition, the correlation between work position and physical fatigue had a positive value, so the variables correlated in one way direction. These results are in accordance with the results of research from (Amalia, Wahyuni and Ekawati, 2017) who found correlation between work posture and physical fatigue in workers. This is also similar to research by Mongkareng, Kawatu and Franckie (2018), suggesting that there was a significant correlation between work position with musculoskeletal problems. Work positions in the circular loom and jumbo bag sub units have a job description that demands a lot of body movement. Most of the workers in these sub units (63.3\%) had a very high risk work position. A very high risk category indicates that changes are needed as soon as possible. According to Andreau et al. (2020), fatigue mostly depends on the work position.

The work position of the workers in the circular loom and jumbo bag sub unit requires several movements that form an angle which adds the value to the work position. The movement that forms this angle causes the muscles to contract continuously. If it continues, it can lead to an increase in the levels of lactic acid along with the increased work hours. Work positions that do not comply with the predetermined standards, repetitive activities, unnatural work postures, and body positions far from the center of gravity will cause muscle fatigue (Tarwaka, 2014). If ergonomic status is considered as work position, then this research is in line with Lukman's (2020) research stating that ergonomic status had a significant correlation with work fatigue. The results of the study is also in line with research by (Putriwijaya, Berniyanti and Diyatri, 2016) which found that there was a significant relationship between work position and lactic acid levels with musculoskeletal problems. 


\section{CONCLUSION}

The main problem in the expedition sub units of PT $X$ is worker fatigue. In addition, the researchers also found that the work position was classified as a high risk. Efforts are needed to reduce worker fatigue and work position risks.

\section{ACKNOWLEDGEMENTS}

This research was supported by PT X and the Faculty of Public Health, Airlangga University,Surabaya.

\section{REFERENCES}

Amalia, N. R., Wahyuni, I. and Ekawati, E. (2017) 'Hubungan Postur Kerja dengan Keluhan Kelelahan Kerja pada Operator Container Crane PT. Terminal Peti Kemas Semarang', Jurnal Kesehatan Masyarakat (e-Journal), 5(5), pp. 290-298.

Andersen, L. W. (2013) 'Etiology And Therapeutic Approach To Elevated Lactate', Mayo Clinic Proceeding, 88(10), pp. 1127-1140.

Andreau, O. et al. (2020) 'Influence of the Position and Size of Various Deterministic Defects on the High Cycle Fatigue Resistance of a 316L Steel Manufactured by Laser Powder Bed Fusion', International Journal of Fatigue. 143 pp. 1-34.

Andriani, R. (2016) Hubungan Antara Indeks Massa Tubuh dan Aktivitas Fisik dengan Volume Oksigen Maksimum. Undergraduate Thesis. Surakarta: Faculty of Health Science, Universitas Muhammadiyah Surakarta.

Annisa, R. N. and Farihah, T. (2018) 'Analisa Beban Kerja Fisik Sebagai Dasar Penentuan Waktu Istirahat yang Optimal (Studi Kasus Di PT. X)', Integrated Lab Journal, 5(1), pp. 1-12

Budhiman, M. A. (2015) Analisis Penilaian Tingkat Risiko Ergonomi Pada Pekerja Konstruksi Proyek Ruko Graha Depok Tahun 2015. Undergraduate Thesis. Jakarta: Faculty of Medicine and Health Sciences, Universitas Islam Negeri (UIN) Syarif Hidayatullah.

Eko, N. (2014) 'Ergonomi Konsep Dasar dan Aplikasi'. Surabaya: Prima Printing.

Gandung (2011) 'Hubungan Sikap Kerja Dengan Kelelahan Kerja Pekerja Laundry Di Kecamatanpurwokerto Utara Kabupaten Banyumas', Jurnal Kesmasindo, 7(3), pp. 209-217.
Gorostiaga, E. M. et al. (2010) 'Vertical Jump Performance and Blood Ammonia and Lactate Levels during Typical Training Sessions in Elite 400-M Runners', Journal of Strength and Conditioning Research, 24(4), pp. 1138-1149.

Gorostiaga, E. M. et al. (2014) 'Blood Ammonia and Lactate As Markers of Muscle Metabolites during Leg Press Exercise', Journal of Strength and Conditioning Research, 28(10), pp. 2775-2785.

Hasibuan, M. S. P. (2016) Manajemen Sumber Daya Manusia. Bumi Aksara.

Hidayah, I. (2018) 'The Increased of Lactid Acid Concentration in The Blood After Work', The Indonesian Journal of Occupational Safety and Health, 7(2), pp. 131-141.

Jalajuwita, R. N. and Paskarini, I. (2015) 'Hubungan Posisi Kerja dengan Keluhan Muskuloskeletal Pada Unit Pengelasan PT. X Bekasi', The Indonesian Journal of Occupational Safety and Health, 4(1), pp. 33-42.

Jia, Y., Wang, Y. and Yu, X. (2017) 'Relationship between Blood Lactic Acid, Blood Procalcitonin, C-Reactive Protein and Neonatal Sepsis and Corresponding Prognostic Significance in Sick Children', Experimental and Therapeutic Medicine, 14, pp. 2189-2193.

Kurnianto, D. (2015) 'Menjaga Kesehatan di Usia Lanjut', Jurnal Olahraga Prestasi, 11(2), pp. 19-29.

Leksana, E. (2010) 'Kadar Laktat sebagai Parameter Resusitasi', Cermin Dunia Kedokteran, 37(7), pp. $545-548$.

Lukman, M. S. (2020) 'Factors Associated with Work Fatigue Symptoms on Bus Service Officers of PT TransJakarta Corridor VI Ragunan', 14(2), pp. 64-68.

Mongkareng, E. R., Kawatu, P. A. T. and Franckie, R. R. (2018) 'Hubungan Antara Masa Kerja Dan Posisi Kerja Dengan Keluhan Musculoskeletal Pada Pekerja Pembuat Babi Guling Di Kelurahan Kolongan Kota Tomohon', Jurnal KESMAS, 7(5), pp. 1-9.

Ningrum, D. A. (2012) Perbandingan Metode Hydrotheraphy Massage dan Massage Manual Terhadap Pemulihan Kelelahan Pasca Olahraga Anaerobic Lactacid. Undergraduate Thesis. Bandung: Faculty of Sports and Health Education, Universitas Pendidikan Indonesia.

Putriwijaya, F. D., Berniyanti, T. and Diyatri, I. (2016) 'Correlation Between Working Positions and Lactic Acid Levels with Musculoskeletal Complaints among Dentists', Dental Journal 
(Majalah Kedokteran Gigi), 49(4), pp. 201205.

Sari, D. N., Endardjo, S. and Santoso, D. I. S. (2013) 'Blood Lactate Level in Wistar Rats after Four and Twelve Weeks Intermittent Aerobic Training', Medical Journal of Indonesia, 22(3), pp. 141-145.

Setiadi, K. (2015) Hubungan Antara Usia dan Indeks Massa Tubuh dengan Kadar Asam Urat pada Remaja di SMA Negeri 1 Samarinda. Undergraduate Thesis. Samarinda: Nursing Science Study Program, Sekolah Tinggi Imu Kesehatan Muhammadiyah.

Setyawati (2010) Selintas Tentang Kelelahan Kerja. Yogyakarta: Asmara Books.

Sugiyono (2008) 'Metode Penelitian Kuantitatif Kualitatif dan R\&D'. Jakarta-Indonesia.: CV. Alfabeta, Bandung.
Sulaiman, F. and Sari, Y. P. (2016) 'Analisis Postur Kerja Pekerja Proses Pengesahan', Jurnal Teknovasi, 3(1), pp. 16-25.

Suma'mur (2009) Hiegine Perusahaan dan Keselamatan Kerja. Jakarta: CV Sagung Seto.

Tarwaka (2014) Keselamatan dan Kesehatan Kerja "Manajemen dan Implementasi K3 di Tempat Kerja"'. Surakarta: Harapan Press, Surakarta.

Umyati (2010) Faktor Faktor Yang Berhubungan Dengan Kelelahan Kerja Pada Pekerja Penjahit Sektor Usaha Informal Di Wilayah Ketapang Cipondoh Tangerang Tahun 2010. Undergraduate Thesis. Jakarta: Faculty of Health Sciences, Universitas Islam Negeri Syarif Hidayatullah.

Widiastuti, S. and Dieny, F. F. (2015) 'Faktor Determinan Produktivitas Kerja Pada Pekerja Wanita', Jurnal Gizi Indonesia (The Indonesian Journal of Nutrition), 4(1), pp. 28-37. 